
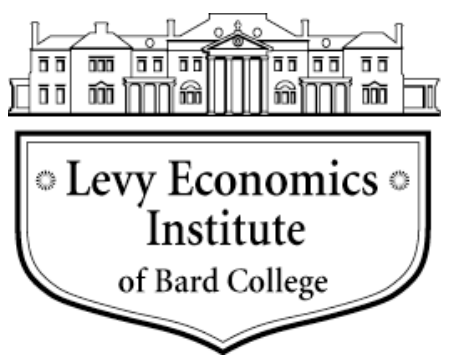

Working Paper No. 691

\title{
Unpaid and Paid Care: The Effects of Child Care and Elder Care on the Standard of Living*
}

by

\author{
Kijong Kim and Rania Antonopoulos \\ Levy Economics Institute of Bard College
}

October 2011

* This paper is largely drawn from the authors' previous work with two other scholars, Thomas Masterson and Ajit Zacharias of the Levy Economics Institute of Bard College (Antonopoulos, Kim, Masterson, and Zacharias 2010). The authors thank them for their superb competency and collegiality.

The Levy Economics Institute Working Paper Collection presents research in progress by Levy Institute scholars and conference participants. The purpose of the series is to disseminate ideas to and elicit comments from academics and professionals.

Levy Economics Institute of Bard College, founded in 1986, is a nonprofit, nonpartisan, independently funded research organization devoted to public service. Through scholarship and economic research it generates viable, effective public policy responses to important economic problems that profoundly affect the quality of life in the United States and abroad.

Levy Economics Institute P.O. Box 5000

Annandale-on-Hudson, NY 12504-5000

http://www.levyinstitute.org 


\begin{abstract}
Transforming care for children and the elderly from a private to a public domain engenders a series of benefits to the economy that improve our standard of living. We assess the positive impacts of social care from both receivers' and providers' points of view. The benefits to care receivers are various, ranging from private, higher returns to education to enhancing subjective well-being and health outcomes. The economy-wide spillovers of the benefits are noteworthy. Early childhood education reduces costs of law enforcement and generates higher long-term economic growth. Home-based health care lowers absenteeism and job losses that otherwise undermine labor productivity, providing adequate care at a lower cost and delaying admission into high-cost institutional care. Social care improves mothers' labor-market attachment with higher lifetime income; it also lowers physical and psychological burdens of elder care that are becoming more prevalent with an aging population. Social care investment creates more job opportunities than other public spending, especially for workers from poor households and with low levels of educational attainment. The broad contributions of social care to our standard of living should be recognized in the public discourse, particularly in this era of fiscal austerity.
\end{abstract}

Keywords: Child Care; Elder Care; Social Care; Quality of Life

JEL Classifications: J13, J14, J48 


\section{INTRODUCTION}

The purpose of this paper is to explore how much service provisions of child care and elder care improve the quality of life for care receivers, caregivers, and society. A review of the literature on early childhood development, long-term health, and geriatric care reveal the economic and social benefits of child and elder care. We also identify gaps between supply and demand of care services; we propose that public provision of child and elder care can address the gap. Furthermore, the expansion is an effective and equitable job creation policy that benefits women and the poor more than conventional, infrastructure-building public job programs.

The literature on education and economics has pointed out the long-term gains from intensive early childhood education. The direct gains that accrue to treated individuals are higher educational attainment, higher wage earnings, and higher asset ownership, among others. Society also benefits from early childhood education through lowered crime rates and costs related to law enforcement. The literature on geriatric and hospice care indicates that patients and their family caregivers benefit from home-based care: higher emotional and social function, better health outcomes for patients, and lesser damage to the health of caregivers. The conflict between unpaid care at home and paid work from employment and potential loss of productivity can be mitigated by home-based care services. The evidence of individual benefits and positive externalities to our society justify the expansion of social care through public provision.

Demands for care services are growing as the baby-boomers are aging and advances in medicine prolong the life expectancy of seniors with medical conditions. Demand for early childhood development programs - in the form of preschool and educational daycare - is expected to rise; as public awareness of the benefits of early childhood development increases, so too will the demand for these programs. And yet, neither private supply nor public coverage through entitlement programs matches the demand for care. There is a big room for expansion of the care provision.

We evaluate the employment and distributional impacts of social care expansion, vis-àvis infrastructure investment, largely drawn from Antonopoulos et al. (2010). Social care investment creates twice as many jobs overall, 16 times more jobs for women, and 2.5 times more jobs for low-income households (first through fourth decile) than infrastructure construction does. These findings highlight the inclusive nature of social care investment that addresses chronic unemployment and poverty of disadvantaged workers. 
Expanding coverage of existing programs - home healthcare under Medicare and Medicaid, Head Start and Early Head Start for low-income families, and state and local Pre-K programs - should be effective. To enhance the incentive for a higher quality of service, we should invest in program innovations and consider higher hourly wages for care workers.

\section{BENEFITS OF SOCIAL CARE}

\section{Lifetime Skills Acquisition to Future Economic Prosperity}

Early Childhood Education (ECE) is aimed at providing children under the age of five with a positive and stimulating environment for their cognitive and noncognitive development, which is crucial in the fulfillment of an individual's future potential. Child care providers-mainly child care workers and preschool teachers and assistants—offer a safe and nurturing environment in which children socialize with others and learn basic skills for daily routines. They also organize activities to enhance children's physical, emotional, and intellectual abilities. Early childhood development, a component of child care in the context of education, has received strong public support for its contribution to children's cognitive and noncognitive development and consequent benefits to individuals and society.

A series of program evaluations of high-quality, intensive pilot projects - the Abecedarian project in North Carolina, High/Scope Perry Preschool study, and Title I Chicago Child-Parent Centers, for instance - find that the early education programs have long-term benefits in terms of academic achievement and better labor market outcomes for children when they reach adulthood. The community has also benefited from fewer crimes and higher productivity of the participants. ${ }^{1}$

Children who participate in the ECE programs benefit from cognitive and noncognitive development. Cognitive skill development is essential for successful academic performance and ECE makes significant impacts (Helburn 1995; Peisner-Feinberg et al. 1999). Children who participated in the Abecedarian project retain higher levels of cognitive skills into their adulthood and are more likely to enroll in higher education (Campbell et al. 2001; 2002). Even

\footnotetext{
${ }^{1}$ Gollin, Mitchell, and Gault (2004) provide a concise summary of literature review on this topic. Additional references include Currie (2001), Barnett et.al (2004), and Barnett, Lamy, and Jung (2005). Almond and Currie (2010) conduct an extensive review of theoretical and empirical studies on the effects of early childhood experiences and human capital formation. They reiterate the importance of early intervention that can remediate negative episodes in early childhood that otherwise would leave life-time damage to the children.
} 
the less intensive programs-High/Scope Perry Preschool and Title I Chicago Child-Parent Center-have significant impacts on children in terms of school achievement, test scores, and lower grade retention (Schweinhart, Barnes, and Weikart 1993; Barnett 1996). ECE has a lasting impact on children: At age 40, the participants of High/Scope Perry preschool programs are more likely to be employed (76 percent versus 62 percent) and have higher median annual earnings ( $\$ 20,800$ versus $\$ 15,300)$ than nonparticipants in the control group. The participants are also more likely to own homes ( 37 percent versus 28 percent), cars ( 82 percent versus 60 percent), and savings accounts ( 76 percent versus 50 percent). These indicators of economic well-being should be kept in mind when accounting for benefits of ECE in the long run.

Noncognitive skills—-persistence, self-esteem, social skills, and other emotional and personal traits - are crucial in determining schooling, occupational choices, work experiences, and participation of adolescent risky behaviors (Heckman, Stixrud, and Urzua 2006; Heckman and Masterov 2007). They find that the impact of ECE lies in improving noncognitive skills, as much as cognitive skills, of children at an early age. They further claim that early intervention can mediate, and even prevent, the skill gaps for the children from disadvantaged families whose environment and parenting are less than conducive especially for noncognitive development.

The role of ECE as an economic development and growth strategy has been a subject of another stream of research. Dickens, Sawhill, and Tebbs (2006) claim that universal preschool investment would increase children's educational attainment, in other words, an increase in stock of human capital in the economy. The higher level of human capital in turn raises gross domestic product (GDP) and household income. Consequently, the increased income would generate more investment in human capital, which enforces the virtuous cycle of education and growth in the future. The overall impact of the investment is estimated to be an extra 3.5 percent growth in GDP by the year 2080, compared to their baseline projection. Bartik (2006) also presents similar simulation results for universal early education programs: ECE promotes higher educational attainment and consequent human capital that makes workforce more productive and employable. He compares this simulation to a case in which states use business development subsidies for economic development, and finds that universal ECE programs generate more long-term economic benefits than the subsidies in terms of earnings, job creation, gross domestic product, and government tax revenue. These long-term benefits come to realization in the long run as the more and better-educated workforce enters the labor market. 
Heckman (2011) further asserts that the advantage of early childhood development can reduce racial gaps in income level in the United States.

\section{Home-based Healthcare for the Elderly and Higher Satisfaction and Health Outcome}

Home-based healthcare services provide assistance to people with disabilities or chronic medical issues, the cognitively impaired, and older adults living in their own homes. They help patients with some basic medical care - monitoring patients' vital signs, administering medication, managing chronic conditions - under the direct supervision of a medical professional, such as a registered nurse or a patient's physician. The aides also assist with daily activities, exercise, and provide emotional support. The care enables patients to maintain individual freedom and an independent lifestyle and to cope with illness in a more familiar environment.

An estimated 1.46 million patients were receiving home care on a given day in 2007 with 315 days of mean length of service, and another one million patients were discharged from hospice care with 65 days of service on average, according to the National Home and Hospice Care Survey by the Center for Disease Control and Prevention. The Department of Health and Human Services projects that 27 million people will need some type of long-term care by 2050; of those the majority will receive home-based healthcare and hospice care (Caffrey et al. 2011).

Functional independence is a key goal of geriatric healthcare, and providing care in the home provides an environment to achieve goals that are not available in the office settings (Duffy 2010, p.348). It is also true for younger, disabled people with long-term health issues. The sense of independence, personal comfort, and social inclusion with family and community enhances the emotional quality of life of patients, as well as caregivers. To improve the quality of life of patients and their families is the goal of hospice care. Hospice care focuses on managing symptoms, alleviating physical and emotional sufferings, and assisting end-of-life decision-making. The vast literature on palliative care finds significant improvement in the quality of life of those who receive end-of-life care.

The vast literature on gerontology and palliative care finds home-based healthcare to improve medical outcome and quality of life of both patients and family caregivers. Among various studies on the topic, Hughes et al. (2000) find that home-based primary care with support from a team of nurses, social workers and physicians improves health-related quality of life - especially emotional, social function and mental health — of patients and their caregivers. 
It also effectively reduces objective and subjective care burdens. Home-based palliative care has become a popular care option for terminally-ill patients. Brumley, Enguidanos, and Cherin (2003) and Peters and Sellick (2006) find that home-based care offers a higher quality of life through perceived control over their illness and depression, and significantly fewer emergency room visits and hospitalization.

External assistance for management of home-based care with a carefully designed individualized care plan and regular monitoring improves quality of care. In a randomized trial, Counsell et al. (2006) find that a home-based geriatric care management system developing individualized care plans and monitoring low-income elderly patients yields better health status, greater functional independence at home, fewer emergency room visits and hospitalizations, and fewer nursing home days. In their subsequent study, Counsell et al. (2007) measure more detailed medical outcomes, including social functioning and mental health, and find significant improvement for the treatment group compared to the controlled group. The psychological quality of life of the treated seniors has improved significantly as well. The evaluation of randomized trials on indirect assistance to home-based care finds that the managed home care improves the quality of life of both patients and caregivers (Hughes et al. 2000; Counsell et al. 2007). The indirect assistance involves a team of nurses, social workers, therapists, and primary physicians that monitors and devises a right care regime and contingent plans for acute care.

\section{Quality of Life of Family Caregivers}

\section{Early Childhood Development: Mothers' Paid Work Participation}

One way to recognize the positive impacts of social care on the quality of living is to recognize the well-being of unpaid family caregivers. The early education programs relieve some of the care burdens of parents, especially mothers. The relief translates into increasing labor market participation of mothers with young children or under public assistance (Kimmel 1995; Powell 1997; Blau and Tekin 2007; Lefebvre and Merrigan 2008). Universal ECE through social care may reduce the wage penalty for motherhood that Budig and England (2001) found in the National Longitudinal Survey of Youth. The economic empowerment from the increased participation and higher wage warrants the improvement in quality of life for mothers.

\section{Home-based Care: Lowering Physical and Psychological Care Burdens}

Physical and psychological burdens of caring for medically-challenged elderly at home are substantial and most of us are bound to meet the challenges sooner or later. An estimated 36.5 
million out of 112.6 million households have at least one unpaid family caregiver within the last twelve months, according to the Caregiving in the U.S. survey. ${ }^{2}$ The survey reveals that women (66 percent) are predominantly caregivers with an average age of 48 years old, caring for people over 50 years old (72 percent of care receivers). On average, caregiving has been ongoing for 4.6 years; 31 percent of caregivers have been caring for their loved ones for five years or more. The caregivers spend 20.4 hours a week on average, with 26 percent spending over 20 hours a week. The burden of care, measured by care time and number of care activities regarding daily living, is high for 32 percent of caregivers. The main reason for care needs are old age (12 percent), Alzheimer's or dementia (10 percent), mental/emotional illness ( 7 percent), followed by cancer, heart disease, and stroke, among others, based on the caregivers' reports (NAC 2009).

Gerontology and psychogeriatrics literature have studied extensively the physical and emotional burden - higher levels of anxiety and depression, and anticipatory grief during caregiving — of care for elderly disabled patients (Hughes et al. 2000; Stuckey et al. 1996). Farfan-Portet et al. (2010) find that informal caring burdens coupled with formal employment can harm the caregivers' general health. NAC (2009) reports that 17 percent of caregivers reported worsening health as a result of caregiving, and the longer the caregiving goes on, the more likely the person's health deteriorates. Alzheimer's and dementia are particularly devastating to caregivers (Meuser and Marwit 2001; Pinquart and Sörenson 2003; Cooper, Balamurali, and Livingston 2007). Stress from caregiving negatively influences other areas of daily life of caregivers (Aneshensel et al. 1995). The emotional stress of caregiving is prevalent: three in ten caregivers consider their situation highly stressful (NAC 2009). The social isolation from intense care burden is another stressor for caregivers.

Care responsibilities disrupt caregivers' paid work schedule and sometimes leads to exit from the labor market. Spouses of patients with Alzheimer's disease are more likely to quit paid work (10.6 percent) due to care responsibilities than other caregiving spouses (4 percent), even with coverage of long-term care insurance (MetLife 2006b). NAC (2009) finds that among 70 percent of caregivers who were employed at some time when they were caregiving, two-thirds experienced disruptions in their regular work schedule; one in five took a leave of absence; 12 percent gave up working entirely or chose early retirement. The disruption from unpaid family care also costs employers dearly. MetLife (2006a) reports that over 7 million full-time,

\footnotetext{
${ }^{2}$ An estimated 65.7 million people in the United States have served as unpaid family caregivers to an adult or a child. The National Alliance for Caregiving (NAC) in collaboration with AARP conducted the survey, funded by the MetLife foundation. The 2009 survey is the third of its series, following 1997 and 2004 studies.
} 
employed caregivers provide "intense" care and experience various types of paid work disruptions. And the conservative estimated cost to employers is $\$ 17.1$ billion in the United States a year. ${ }^{3}$

Active intervention and assistance, in particular home care services, can reduce the care burden. Family intervention - a combination of direct care provision, family therapy, and assistance with information and organizing outside care - is found to be an effective method to reduce the care burden of patients with Alzheimer's disease (Marriott et al. 2000; Gitlin et al. 2003; Sörensen, Pinquart, and Duberstein 2002). The community-based services - in-home help and adult daycare-lower the stress of caregiving as well (Gaugler et al. 2005). In particular, use of home care and respite services effectively reduce caregivers' burdens and improves quality of life (Kumamoto, Arai, and Zarit 2006; Lund, Wright, and Caserta 2005).

\section{GAPS IN DEMAND AND SUPPLY OF SOCIAL CARE}

\section{Early Childhood Development: More Than a Third}

Hidden demand for early childhood development services is larger than officially recognized. One way to estimate this demand is by counting the number of child care providers other than formal paid child care workers, including unpaid care by relatives: There are 1.9 non-parental, paid and unpaid care givers for every paid care workers captured in the official survey (Burton et.al. 2002; Warner 2009). According to the National Household Education Surveys Program of 2005, sixty percent of children under the age of five have at least one weekly non-parental care arrangement. Among those who have the arrangements, 60 percent participate in center-based care, 35 percent in relative care, and 22 percent in non-relative care (Iruka and Carver 2006). ${ }^{4}$ For over 2 million 3- and 4-year-olds from poor families in the bottom fifth, over a third of them are not enrolled in any center-based program (Haskins and Barnett 2010). International comparison puts the current situation into perspective. The enrollment in center-based care is below the Organization for Economic Co-operation and Development (OECD) average of 77 percent, which puts the United States among the bottom six (OECD 2011).

\footnotetext{
${ }^{3}$ In terms of time commitment, the intense caregiving takes 12 to 87 hours per week. A broader measure, including caregivers of all levels of burden, estimates the costs to employers at $\$ 33.6$ billion. The base prices are median salary or wages of men and women, and applied to the number of full-time, employed caregivers, whose full-time paid work are disrupted in the form of absenteeism, unpaid leave, reduced work hours, and/or permanent leave. Note that under the equal pay principle, the costs would be even higher, as women tend to be the primary caregivers.

${ }^{4}$ The sum is greater than 100 percent because some children have multiple care arrangements.
} 
The financial burden of care is also distributed unequally: an average family below the poverty level spends 29.2 percent of their income, while a typical family above 200 percent of the poverty level spends only 8.3 percent on child care, according to the Survey of Income and Program Participation by the U.S. Census Bureau in 2006. Even with federal and state subsidies and grants, child care expenditure is a large financial burden to many families.

\section{Home-based Care: Aging Population}

Demand for home-based care is rapidly increasing as baby boomers are aging and advanced medical technologies are extending the life expectancy of disabled and chronic patients. By 2050, an estimated 27 million people will need some type of long-term care (Department of Health and Human Services 2003). According to the National Home Health Aide Survey (NHHAS), ${ }^{5}$ almost 1.46 million people were receiving care in 2007 and 7.2 million people had received care and been discharged in $2000 .{ }^{6}$ Over 14,000 agencies are in the business of recruiting and training caregivers and serving patients. ${ }^{7}$ The home healthcare and aide workers provide over 70 percent of the paid long-term medical care and personal assistance. Over $\$ 58$ billion - or 2.76 percent of the national health expenditure - was spent on home health service in 2006. ${ }^{8}$ Medicare and Medicaid cover the bulk of total home healthcare service payments, 37 and 19 percent respectively, according to National Association for Home Care and Hospice (NAHH 2008). Home healthcare accounts for 3.9 percent of Medicare spending in 2006 and 16.3 percent of Medicaid expenditures in $2004 .{ }^{9}$ Nonetheless, it is individual effort that contributes the most to care: family, friends, and other volunteers cover 57 percent (36 percent by informal care and 21 percent by out-of-pocket payments) of long-term care responsibilities for the elderly (CBO 2004). Medicare and Medicaid pick up 38 percent of total costs, followed by private insurance ( 3 percent) and other ( 2 percent).

\section{How to Fill the Gaps}

Administration of investment in expanding social care does not require an equal expansion of

\footnotetext{
${ }^{5}$ The 2007 survey collected data only on current care recipients. The previous surveys, from 1996 through 2000, show 7.2 to 7.7 million discharges. Given this trend, it is reasonable to assume 7 million discharges in 2007. Trend tables from the survey are available from the National Center for Health Statistics at http://www.cdc.gov/nchs/nhhcs/nhhcs patient trends.htm (last accessed on September 30, 2011)

${ }^{6}$ According to the 1996, 1998, and 2000 surveys, the annualized discharge numbers are between 7.2 to 7.7 million. It seems reasonable to assume that the discharge number in 2007 would be around 7 million.

${ }^{7}$ The number includes hospice care agencies that may or may not provide home health care in addition.

${ }^{8}$ In 2008, expenditure on home healthcare exceeded $\$ 65$ billion, according to Centers for Medicare and Medicaid Services.

${ }^{9}$ See National Association for Home Care and Hospice (2008) for more information.
} 
government size, nor a novel approach to channel the funds through the system. The delivery systems are already organized and administered by federal, state, and local governments through Head Start/Early Head Start, Pre-K programs, and various home-based care organizations that qualify for reimbursement from Medicare and Medicaid. Scaling up implicates the increase in enrollment into the care system as well as the extension of the coverage period and spending cap on the services. The current cap of 100 days of services under Medicare is far below the average length of home-base care. The expansion does not entail compromises on the quality of care or skill mismatch of newly hired workers. Skill requirements and training time may not be as onerous as that for some construction-related jobs. A good deal of physical stamina and aptitude for care for others may be enough to begin with. Then, through on-the-job training with a current child development associate degree and/or home health aide certification, concerns for high quality care could be addressed. Scaling up service delivery would not overwhelm the system or require extra federal scrutiny. Concerns about fraud and abuse of funds for Medicaid and Medicare have already attracted the government's due diligence with successful enforcement under the newly enacted Affordable Care Act.

Public expenditure on child care and early education programs in the United States is less than 0.4 percent GDP, which puts the country in twenty-seventh out of 37 developed countries (OECD 2011). Even for early education programs alone (0.25 percent), we are not doing any better. There is certainly room for the government's support and initiative.

\section{CURRENT WORKERS IN THE CARE SECTOR}

The child care and early childhood development providers in the industry are mainly preschool teachers ( 35 percent of total wage and salary jobs in the industry), child care workers (30 percent), and preschool teacher assistants (14 percent) (BLS 2009a). The median age of the providers is 38 and 19 percent of them are 24 years or younger, whereas the median age of all workers in the economy is 45 and only 13 percent of them are 24 or younger. The age composition of the care providers suggests that the occupation may serve as one of the entry jobs for the young and low-skilled population. Education requirements for Pre-K programs, federal Head Start and Early Head Start, and private fee-based programs vary by state, from a high school diploma with Child Development Associate (CDA) degree to a college degree in early childhood education. Family child care providers, in particular in small-scale, informal 
settings, are not under state or federal regulation. The average hourly wage in the industry is $\$ 11.32$, lower than the overall private industry average of $\$ 18.08$. Median annual wages range from $\$ 17,440$ for child care workers, $\$ 22,120$ for preschool teachers, and up to $\$ 37,270$ for preschool directors (BLS 2009b). The lower-than-average weekly earnings of \$345, compared to $\$ 608$ overall in the private industry, imply that many providers work on a part-time basis. Overall, 25 percent of the workers (15 percent for preschool teachers and 30 percent for child care workers) are from families whose total income falls below 150 percent of the official poverty line, of which 9.5 percent received food stamps in the year $2008 .^{10}$

Low-skilled women have dominated the workforce- 88 percent of total care workers (paraprofessionals) - in the home healthcare provision. The average age in the sector is 41 years old. Most are minority (52 percent), especially African American women (30 percent), while recent immigrants make up the other 21 percent of the workforce; 43 percent of the workers are employed part-time in a given year (PHI 2009). No education requirements exist for these jobs, although those who work for an agency receiving Medicare and Medicaid reimbursements are required to pass competency tests or state certification programs with a minimum of 75 hours of training. Fifty-eight percent of workers hold high school diplomas or less. The mean hourly wage of home health aides was $\$ 10.31$ in May 2008 and $\$ 21,440$ per year. Over 25 percent of the workers have incomes below 150 percent of the official poverty line and almost 16 percent of them received food stamps in 2008 (King et.al 2009). Low wage rates may contribute in part to the poor economic status of the workers, but it is also true that many workers come from poor households. Thus, it is hard to establish a causal relationship between low wages and poverty among the workers.

The expansion of service delivery would directly create demand for more preschool teachers and paraprofessionals. Increased demand for material and services to expand the social care sector generates more job opportunities indirectly in the rest of the economy. Taking it a step further, there are distributional consequences depending on who would receive jobs and how much they are likely to earn. In the following section, we discuss the methodology used for the analysis.

\footnotetext{
${ }^{10}$ The estimates are based on a preliminary analysis of the 2009 Annual Social and Economic Supplement of the Current Population Survey (ASEC), compiled and harmonized by King et.al (2009) at the Minnesota Population Center.
} 


\section{METHODOLOGY}

To analyze the employment impact of our proposed intervention we combine two different quantitative methods; at the macro level we make use of input-output analysis and at the micro level we employ a microsimulation model, as described in Antonopoulos et al. (2010). Inputoutput analysis allows for calculation of aggregate changes in employment by industry and occupation, while the microsimulation, based on propensity-score matching, distributes these jobs by matching them to individuals who are most likely to occupy them based on nationally representative survey data. Once we assign jobs, we impute earnings to those individuals who receive a new job, based on their gender, age, marital status, family structure, and industry and occupation assigned to them.

Our policy simulation assumes an investment of $\$ 50$ billion on projects that increase social care provisioning. Divided equally between home-based healthcare and early childhood development for children under the age of five, this amount is equivalent to one half of the total gross output of the two industries combined in 2006. The amount may not be enough to make the services entitlements. It is rather an approximate figure that seems a reasonable figure to start with. The injection of funds into the relevant private sectors, not into general government, reflects the current mechanism for the bulk of service delivery. In other words, although centers that act as service providers must meet certain state-level criteria, these entities are private.

In the following sections, we analyze the results from two case studies on employment, income distribution, and poverty reduction.

\section{EMPLOYMENT AND INCOME DISTRIBUTION}

We analyze the numbers and types of jobs created by social sector expansion, and compare it to the case of infrastructure construction. The care expansion generates more jobs, twice as many as infrastructure construction, and 90 percent of the new jobs are likely to go to women. Disadvantaged workers are more likely to find jobs under the investment in social care than in infrastructure. The labor intensity and composition of workers in the care sector attributes to the findings. Distribution of the new jobs implicates distribution of income from the new jobs. We find "pro-poor" nature of social sector expansion. 


\section{Employment Creation and Distribution}

A 50 percent expansion of the social care sector-early childhood education and home-based care for elderly and chronically ill patients — in terms of gross output in 2006, equivalent to $\$ 50$ billion, generates approximately 1.2 million jobs in the economy, of which 8 out of 10 new jobs $(956,082$ out of $1,186,342)$ are within the care sector, as shown in Table 1 . The same level of expansion in infrastructure construction and maintenance yields half a million jobs, with 6 out of 10 new jobs $(345,955$ out of 555,942$)$ in the construction sector.

Table 1. Total Employment Distribution Across Industries

\begin{tabular}{lrc}
\multicolumn{1}{c}{ Industry } & Social Care & Infrastructure \\
\hline Agriculture & 2,928 & 1,969 \\
Mining & 520 & 2,463 \\
Utilities & 773 & 1,808 \\
Construction & 4,489 & 345,955 \\
Manufacturing & 16,797 & 46,402 \\
Wholesale & 7,139 & 11,421 \\
Retail & 4,432 & 36,628 \\
Transportation and Warehousing & 7,020 & 12,715 \\
Information & 4,989 & 4,312 \\
Financial and Real Estate services & 13,621 & 11,474 \\
Professional and Business services & 57,672 & 55,675 \\
Education & 688 & 719 \\
Healthcare and Social Assistance & 21,046 & 675 \\
Social Care & 956,082 & 107 \\
Leisure and Hospitality & 15,650 & 6,509 \\
Other services & 3,113 & 5,009 \\
Government & 69,384 & 12,099 \\
\hline Total & $\mathbf{1 , 1 8 6 , 3 4 2}$ & $\mathbf{5 5 5 , 9 4 2}$ \\
\hline Source: Antonopoulos et al. (2010) & &
\end{tabular}

Table 2 depicts the job distribution in absolute numbers and shares by various characteristics of the workers hired, including the unemployed and some people out of the labor force for reasons other than retirement or illness. A microsimulation based on propensity-score matching is used to assign the new jobs by matching potential workers' socioeconomic characteristics to the job openings. The gender composition of job assignments shows almost exact inverse ratios between social care and construction. Over 90 percent of jobs go to women in social sector investment, as more than 80 percent of jobs are created within the sector. On the other hand, infrastructure construction generates over 88 percent of jobs for men, as most jobs (almost 71 percent) are created in male-dominated industries - construction and manufacturing. The decomposition of job assignments by educational attainment highlights the greater 
inclusiveness of social care investment. Over 42 percent of jobs generated by the latter go to people with less than a high school diploma, compared to only 14 percent of jobs created by the infrastructure investment for this most disadvantaged group in the labor market. In the infrastructure case, the majority of jobs (62.6 percent) are assigned to workers with high school diplomas. This fact is largely driven by the construction-related jobs typically held by men with high school diplomas. Although social care investment more highly favors the group with less than a high school diploma, it also provides more opportunities to people with at least some higher education than does infrastructure investment (31.1 to 23.4 percent, respectively). This reflects the certificate requirement for preschool teachers and certain child care providers that are under state or federal regulations for reimbursement purposes. On the other hand, infrastructure investment raises the demand for engineers and architects, jobs the Standard Occupational Classification system identifies as a part of the "professional and business services industry and professional occupations." Typically, these occupations require a college-degree level of education, which accounts for the job assignment - in our simulation — to highereducation attainment groups.

The inclusive nature of social care investment is further reinforced by the job assignment by household annual income. Forty-five percent of jobs go to workers from households with income below the fourth decile (approximately $\$ 39,000$ a year). Home health aides, who comprise one of the major occupation groups in social care, are mainly women from lowincome households: 45 percent of the workers are from households under 200 percent of the federal poverty line. ${ }^{11}$ The social care expansion thus aids those workers specifically. The infrastructure case, on the other hand, provides one half of the jobs created to workers from the middle-income group.

\footnotetext{
${ }^{11}$ It is not clear whether the low skill requirements of care work attracts unskilled workers from low-income households or the low wage rates of care work cause workers to be in low-income households. It may be jointly determined, and thus a direction of causality is hard to establish.
} 
Table 2. Distribution of Jobs Created by Social Care and Infrastructure

\begin{tabular}{lcc} 
Social Care & \multicolumn{2}{c}{ Jobs Assigned } \\
& Number & Percent \\
\hline Gender & & \\
Male & 116,525 & 9.9 \\
Female & $1,059,401$ & 90.1 \\
\hline Education & \\
\hline Less than HS & 500,959 & 42.6 \\
\hline HS Grad & 308,810 & 26.3 \\
\hline Some College & 196,407 & 16.7 \\
College Grad & 169,750 & 14.4 \\
\hline HH Income & & \\
$1^{\text {st }}-4^{\text {th }}$ decile & 530,763 & 45.1 \\
\hline $5^{\text {th }}-8^{\text {th }}$ decile & 395,846 & 33.7 \\
\hline $9^{\text {th }}-10^{\text {th }}$ decile & 249,330 & 21.2 \\
\hline Total & $1,175,939$ & 100.0 \\
\hline Source: Antonopoulos et al. (2010)
\end{tabular}

\begin{tabular}{lrr} 
Infrastructure & \multicolumn{2}{c}{ Jobs Assigned } \\
& Number & Percent \\
\hline Gender & & \\
Male & 489,814 & 88.6 \\
Female & 63,051 & 11.4 \\
\hline Education & \\
Less than HS & 77,482 & 14.0 \\
HS Grad & 345,897 & 62.6 \\
\hline Some College & 46,609 & 8.4 \\
College Grad & 82,877 & 15.0 \\
\hline HH Income & & \\
$1^{\text {st }}-4^{\text {th }}$ decile & 194,915 & 35.3 \\
\hline $5^{\text {th }}-8^{\text {th }}$ decile & 279,438 & 50.5 \\
$9^{\text {th }}-10^{\text {th }}$ decile & 78,516 & 14.2 \\
\hline Total & 552,869 & 100.0 \\
\hline
\end{tabular}

\section{Impacts on Income Distribution}

Tables $3 \mathrm{a}$ and $3 \mathrm{~b}$ show the changes in individual median and mean earnings of those who are assigned jobs in social care and infrastructure construction. The comparison highlights the disparate distributional impacts of the two investments. It is noteworthy to mention that the mean-to-median earnings ratio decreases as the level of educational attainment increases among workers. It is more so for workers in social care than in infrastructure construction, which is indicative of the stronger equalizing effect of social care investment.

Workers with less than a high school diploma tend to benefit the most in relative terms from both of the simulated investments compared to workers with higher levels of educational attainment. Their median and mean earnings increase the most among all the groups. Infrastructure construction turns out to raise earnings of the least educated workers more than social care investment does. The result is attributable to much higher hourly wage rates of construction workers-\$21.87 on average within the industry (BLS 2009c). Even unskilled construction laborers earn more than $\$ 14.30$ per hour, significantly more than the $\$ 11.30$ per hour that a preschool teacher earns on average. For the least-educated workers in social care, exante median earnings $(\$ 3,120)$ are less than half of mean earnings $(\$ 7,641)$, which suggests a highly skewed distribution of the least educated workers along their earnings level. Thus, the likely outcome of the social care investment would be close to the median earnings change for the workers. 
Table 3a. Changes in Median Earnings by Individual Social Care

\begin{tabular}{l|rrr|rrr|} 
Education & Before & $\begin{array}{c}\text { After } \\
\text { Less than HS }\end{array}$ & $\begin{array}{c}\text { Change } \\
(\%)\end{array}$ & Before & After & $\begin{array}{c}\text { Change } \\
(\%)\end{array}$ \\
\hline HS Grad & 3,120 & 7,000 & 124.4 & 7,000 & 17,000 & 142.9 \\
Some college & 15,000 & 26,500 & 76.7 & 18,000 & 30,000 & 66.7 \\
\hline College Grad & 14,000 & 30,000 & 114.3 & 15,000 & 30,002 & 100.0 \\
\hline Income & 26,000 & 55,000 & 111.5 & 28,000 & 52,000 & 85.7 \\
$1^{\text {st }-4^{\text {th }} \text { decile }}$ & & & & & & \\
$5^{\text {th }}-8^{\text {th }}$ decile & 7,000 & 22,029 & 214.7 & 8,060 & 27,500 & 241.2 \\
$9^{\text {th }}-10^{\text {th }}$ decile & 20,000 & 30,000 & 50.0 & 22,000 & 33,000 & 50.0 \\
\hline
\end{tabular}

Source: Antonopoulos et al. (2010)

Table 3b. Changes in Mean Earnings by Individual

\begin{tabular}{l|rcr|rrr|}
\hline Education & \multicolumn{3}{|c|}{ Social Care } & \multicolumn{3}{c}{ Infrastructure } \\
& Before & After & $\begin{array}{c}\text { Change } \\
(\%)\end{array}$ & Before & After & $\begin{array}{c}\text { Change } \\
(\%)\end{array}$ \\
\hline Less than HS & 7,641 & 12,893 & 68.7 & 11,583 & 21,900 & 89.1 \\
\hline HS Grad & 21,654 & 31,382 & 44.9 & 23,163 & 35,304 & 52.4 \\
\hline Some college & 22,950 & 33,169 & 44.5 & 23,994 & 33,960 & 41.5 \\
College Grad & 44,475 & 67,694 & 52.2 & 45,693 & 69,284 & 51.6 \\
\hline Income & & & & & & \\
$1^{\text {st }}-4^{\text {th }}$ decile & 9,940 & 29,862 & 200.4 & 10,863 & 33,787 & 211.0 \\
$5^{\text {th }}-8^{\text {th }}$ decile & 23,503 & 40,183 & 71.0 & 25,227 & 43,875 & 73.9 \\
$9^{\text {th }}-10^{\text {th }}$ decile & 50,810 & 46,903 & -7.7 & 55,879 & 51,569 & -7.7 \\
\hline
\end{tabular}

Source: Antonopoulos et al. (2010)

For workers with higher educational attainment (some college or more), social care investment appears to raise median earnings relatively more than infrastructure construction investment does. The occupational composition of the jobs created by social care investment may explain the difference: the sector hires more managers and professionals than infrastructure, and these jobs, unlike the lower-skilled occupations, usually offer wages comparable to similar jobs in the construction sector. Thus, social care investment appears to be more beneficial to highly educated workers than to those with the least education in terms of earnings. But one should note that social care investment generates many more jobs for workers with less than a high school diploma $(500,959)$ than does infrastructure construction $(77,482)$.

Workers from the poorest households (first through fourth) definitely receive the largest jump in earnings: a more than 200 percent increase in all measures from both types of investment. The very low initial earnings of the group are attributable to the jump. Earnings for workers from middle-income households (fifth through eighth) increase by more than 50 percent, and the infrastructure investment seems to be a slightly better investment for that group. Workers from high-income households (ninth through tenth) show a moderate gain in median 
earnings but a moderate loss in mean earnings. This result implies that earnings from their new jobs are below the earnings from their previous jobs. It may be indicative of a downward transition of some of the newly hired workers from the high-income groups. Again, the infrastructure investment raises the earnings of all groups more than the social care investment does, simply due to relatively higher wage rates in construction industries.

\section{DISCUSSION}

We review how social care enhances the quality of life of individuals receiving and giving care: through better lifetime economic well-being, improved health and satisfaction, and lowering care burdens that leads to stronger attachment to paid work and lower stress of care. These benefits also spill over to society and result in economic growth and savings in public safety and healthcare system. These findings from the literature support the notion of "social care"-public provision of care services to young children, elderly and disabled—and the meaningful expansion of services to improve the quality of life, especially in times of prolonged recession.

The hidden and increasing demand for the services echoes the need for expanding the public provision. Over a third of young children under the age of four from poor families are not enrolled in any center-based program. A majority of the absent children stay at home during the critical time period in which they build the skills that could change their future trajectory of well-being. A growing population of aging baby boomers implicates excess demand of homebased healthcare that may not be met under the current trend of growth in the care industry. The multitude of suffering of caring for sick family members is likely to degrade the quality of life of many more family caregivers.

We propose expanding current public care systems of federal, state, and local programs - Head Start, Early Head Start, and Pre-K, and Medicare and Medicaid long-term care coverage. The expansion does not necessarily entail an enlarged bureaucratic structure.

Governments-federal, state, and local-all have their organizational and administrative systems in place through Medicare, Medicaid, Head Start and Early Head Start, and the Child Care and Development Fund. Scaling up the federal funding to these programs would be a good start.

The survey of care workforce reveals that women, especially minorities and immigrants from poor households, are likely to benefit from the newly created jobs in the care sector. We conduct policy simulations of social care and infrastructure investments and compare the job 
creation potentials and distributional consequences. We find that investment in social care provision can generate twice as many jobs as infrastructure construction. At the same time, the jobs created by social care investments are more beneficial for women, the less-educated, and the poor than those created by infrastructure investment: more jobs are likely to be taken by people from disadvantaged groups and the marginal impacts on earnings are highest for them as well. Even within the poor households, the care sector is more likely to hire workers from the lower end of the income scale than the construction sector is, based on the ex-ante median and mean earnings data for the workers. Social care investment would be an effective policy to address the expected increase in household poverty through long-term unemployment and forced premature retirement from the long "Great Recession." Improvement in the quality of life for all participants in social care and society as a whole seems worth more than what it would cost—a profitable social proposition. 


\section{REFERENCES}

Almond, Douglas and Janet Currie. 2010. "Human Capital Development before Age Five." NBER Working Paper 15827. Cambridge, MA: National Bureau of Economic Research.

Aneshensel, C.S., L.I. Pearlin, J.T. Mullan, S.H. Zarit, and C.J. Whitlatch. 1995. Profiles in caregiving: The unexpected career. San Diego: Academic Press.

Antonopoulos, Rania, Kijong Kim, Thomas Masterson, and Ajit Zacharias. 2010. "Investing in Care: A Strategy for Effective and Equitable Job Creation.” Working Paper 610. Annandale-On-Hudson, NY: Levy Economics Institute of Bard College.

Barnett, W.S. 1996. Lives in the balance: Age-27 benefit-cost analysis of the High/Scope Perry Preschool Program (Monographs of the High/Scope Educational Research Foundation, 11). Ypsilanti, MI: High/Scope Press.

Barnett, W.S., J.T. Hustedt, K.B. Robin, and K.L. Schulman. 2004. The State of Preschool: 2004 State Preschool Yearbook. New Brunswick, NJ: National Institute for Early Education Research.

Barnett, W.S., C. Lamy, and K. Jung. 2005. The Effects of State Prekindergarten Programs on Young Children's School Readiness in Five States. New Brunswick, NJ: National Institute for Early Education Research.

Bartik, Timothy J. 2006. Taking Preschool Education Seriously as an Economic Development Program: Effects on Jobs and Earnings of State Residents Compared to Traditional Economic Development Programs. Research Report. Kalamazoo, MI: W.E. Upjohn Institute for Employment Research.

Blau, David and Erdal Tekin. 2007. "The Determinants and Consequences of Child care Subsidies for Single Mothers in the USA.” Journal of Population Economics 20 (4): 719-741.

Bianchi, Suzanne. 2004. "Gender and time: The subtle revolution in American family life." Paper presented at the Health and Society Scholars Program, University of Pennsylvania.

Bianchi, Suzanne, Melissa Milkie, Liana Sayer, and John Robinson. 2000. "Is anyone doing the housework? Trends in the gender division of household labor." Social Forces 79: 191228.

Budig, Michelle J., and Paula England. 2001. "The Wage Penalty for Motherhood.” American Sociological Review 66 (2): 204-225.

Bureau of Labor Statistics (BLS). 2009a. "Career Guide to Industries, 2010-2011 Edition.” U.S. Bureau of Labor Statistics Office of Occupational Statistics and Employment Projections. Washington, DC. 
. 2009b. “Occupational Employment and Wages, May 2008.” U.S. Bureau of Labor Statistics Office of Occupational Statistics and Employment Projections. Washington, DC.

-.2009c. Occupational Outlook Handbook, 2010-2011 Edition. U.S. Bureau of Labor Statistics Office of Occupational Statistics and Employment Projections. Washington, DC.

Brumley, Richard D., Susan Enguidanos, and David A. Cherin. 2003. Journal of Palliative Medicine 6 (5): 715-724.

Burton, Alice, March Whitebook, Marci Young, Dan Bellm, and Claudia Wayne. 2002.

"Estimating the Size and Components of the U.S. Child Care Workforce and Care giving Population: Key Findings from the Child Care Workforce Estimate (Preliminary Report)." Center for the Child Care Workforce, Washington, D.C. and Human Services Policy Center at the University of Washington, Seattle, WA.

Caffrey, Christine, Manisha Sengupta, Abigail Moss, Lauren Harris-Kojetin, and Roberto Valverde. 2011. "Home Health Care and Discharged Hospice Care Patients: United States, 2000 and 2007." National Health Statistics Reports No.38. Center for Disease Control and Prevention, U.S. Department of Health and Human Services.

Campbell, Frances A., Elizabeth Pungello, Shari Miller-Johnson, Margaret Burchinal, and Craig T. Ramey. 2001. "The Development of Cognitive and Academic Abilities: Growth Curves From an Early Childhood Educational Experiment.” Developmental Psychology 37 (2): 231-242.

Campbell, Frances A., Craig T. Ramey, Elizabeth Pungello, Joseph Sparling, and Shari MillerJohnson. 2002. "Early Childhood Education: Young Adult Outcomes From the Abecedarian Project." Applied Developmental Science 6 (1): 42-57.

Casiro, O.G., M.E. McKenzie, L. McFayden, C. Shapiro, M.M.K. Seshia, N. MacDonald, M. Moffat, and M.S. Cheang. 1993. "Earlier Discharge with Community-based Intervention for Low Birth Weight Infants: A Randomized Trial.” Pediatrics 92 (1): 128-134.

Congressional Budget Office (CBO). 2004. "Financing Long-Term Care for the Elderly." CBO Paper. Washington, DC.

Cooper, C., T.B. Balamurali, and G. Livingston. 2007. "A systematic review of the prevalence and covariates of anxiety in caregivers of people with dementia." International Psychogeriatrics 19 (2): 175-195.

Counsell, Steven R., Christopher M. Callahan, Amna B. Buttar, Daniel O. Clark, and Kathryn I. Frank. 2006. "Geriatric Resources for Assessment and Care of Elders (GRACE): A New Model of Primary Care for Low-Income Seniors." Journal of American Geriatrics Society 54 (7): 1136-1141.

Counsell, Steven R., Christopher M. Callahan, Daniel O. Clark, Wanzhu Tu, Amna B. Buttar, Timothy E. Stump, and Gretchen D. Ricketts. 2007. "Geriatric Care Management for 
Low-Income Seniors: A randomized Controlled Trial.” The Journal of the American Medical Association 298 (22): 2623-2633.

Cunha, Flavio and James J. Heckman. 2008. "Formulating, Identifying and Estimating the Technology of Cognitive and Noncognitive Skill Formation.” Journal of Human Resources 43 (4): 738-782.

Currie, Janet. 2001. "Early Childhood Education Programs." Journal of Economic Perspectives 15 (2): 213-238.

Department of Health and Human Services. 2003. "The Future Supply of Long-Term Care Workers in Relations to the Aging Baby Boom Generation: Report to Congress." Washington, DC.

Dickens, William, Isabel Sawhill, and Jeffrey Tebbs. 2006. "The Effects of Investing in Early Education on Economic Growth." Brookings Institution Policy Brief no.153. The Brookings Institution, Washington, DC.

Duffy, Evelyn G. Wykle. 2010. "Home is Where the Heart is." In May L. and Sarah H. Gueldner, eds., Aging Well: Gerontological Education for Nurses and Other Health Professionals. Sudbury, MA: Jones \& Barlett Learning, LLC.

Farfan-Portet, Maria-Isabel, Frank Popham, Richard Mitchell, Christian Swine, and Vincent Lorant. 2010. "Caring, employment and health among adults of working age: evidence from Britain and Belgium." European Journal of Public Health 20 (1): 52-57.

Gaugler J.E., R.L. Kane, R.A. Kane, and R. Newcomer. 2005. "Early community-based service utilization and its effects on institutionalization in dementia caregiving." Gerontologist 45 (2): $177-185$.

Gitlin, Laura N., Louis D. Burgio, Diane Mahoney, Robert Burns, Song Zhang, Richard Schulz, Steven H. Belle, Sara J. Czaja, Dolores Gallagher-Thompson, Walter W. Hauck, and Marcia G. Ory. 2003. "Effect of Multicomponent Interventions on Caregiver Burden and Depression: The REACH Mutisite Initiative at 6-Month Follow-Up.” Psychology Aging 18 (3): $361-374$.

Gollin, Stacie Carolyn, Anne W. Mitchell, and Barbara Gault. 2004. The Price of School Readiness: A Tool for Estimating the Costs of Universal Preschool in the States. Research Report. Washington, DC: Institute for Women's Policy Research.

Haskins, Ron and W. Steven Barnett. 2010. "Introduction: New Directions for America's Early Childhood Policies." In Ron Haskins and W. Steve Barnett, eds., Investing in Young Children: New Directions in Federal Preschool and Early Childhood Policy. Center on Children and Families at Brookings and National Institute for Early Education Research.

Heckman, James J., Jora Stixrud, and Sergio Urzua. 2006. "The Effects of Cognitive and Noncognitive Abilities on Labor Market Outcomes and Social Behavior." Journal of Labor Economics 24 (3): 411-482. 
Heckman, J.J., and D.V. Masterov. 2007. "The Productivity Argument for Investing in Young Children." Review of Agricultural Economics 29 (3): 446-93.

Heckman, James J. 2011. "The American Family in Black and White: A Post-Racial Strategy for Improving Skills to Promote Equality,” Discussion paper no. 5459, IZA, Bonn.

Helburn, Suzann. 1995. “Cost, Quality, and Child Outcomes in Child Care Centers: Key Findings and Recommendations." Young Children 50 (4): 40-44.

Himmelweit, Susan. 2002. "Making visible the hidden economy: The case for gender-impact analysis of economic policy." Feminist Economics 8 (1): 49-70.

Hughes, Susan L., Frances M. Weaver, Anita Giobbie-Hurder, Larry Manheim, William Henderson, Joseph D. Kubal, Alec Ulasevich, and Joan Cummings. 2000. "Effectiveness of Team-Managed Home-Based Primary Care: A Randomized Multicenter Trial." Journal of the American Medical Association 284 (22): 2877-2885.

Iechovich, Esther. 2008. "Caregiving Burden, Community Services, and Quality of Life of Primary Caregivers of Frail Elderly Persons.” Journal of Applied Gerontology 27 (3): 309-330.

Iruka, I.U., and Carver, P.R. 2006. Initial Results From the 2005 NHES Early Childhood Program Participation Survey (NCES 2006-075). U.S. Department of Education. Washington, DC: National Center for Education Statistics.

Kimmel, Jean. 1995. "The Effectiveness of Child-Care Subsidies in Encouraging the Welfareto-Work Transition of Low-Income Single Mothers." The American Economic Review 85 (2): 271-275.

King, Miriam, Steven Ruggles, Trent Alexander, Donna Leicach, and Matthew Sobek. 2009. Integrated Public Use Microdata Series, Current Population Survey: Version 2.0. [Machine-readable database]. Minneapolis, MN: Minnesota Population Center [producer and distributor].

Kumamoto, Keigo, Yumiko Arai, and Steven H. Zarit. 2006. "Use of home care services effectively reduces feelings of burden among family caregivers of disabled elderly in Japan: preliminary results." International Journal of Geriatric Psychiatry 21 (2): 163170.

Lefebvre, Pierre and Philip Merrigan. 2008. "Child-Care Policy and the Labor Supply of Mothers with Young Children: A Natural Experiment from Canada." Journal of Labor Economics 26 (3): 519-548.

Lund, Dale A., Scott D. Wright, and Michael S. Caserta. 2005. "Respite Services: Enhancing the Quality of Daily Life for Caregivers and Persons with Dementia." Geriatrics and Aging 8 (4): 60-65. 
Marriott, Alison, Catherine Donaldson, Nicholas Tarrier, and Alistair Burns. 2000.

"Effectiveness of cognitive-behavioral family intervention in reducing the burden of care in carers of patients with Alzheimer's disease." The British Journal of Psychiatry 176: $557-562$.

Måvall, L., and M. Thorslund. 2007. "Does day care also provide care for the caregiver?" Archives of Gerontology and Geriatrics 45 (2): 137-150.

McLaughlin, A., F.A. Campbell, E.P. Pungello, and M. Skinner. 2007. "Early educational child care reduces depressive symptoms in young adults reared in low-income families." Child Development 78 (3): 746-756.

MetLife. 2006a. "The MetLife Caregiving Cost Study: Productivity Losses to U.S. Business." Research Report. MetLife Mature Market Institute in Cooperation with National Alliance for Caregiving.

_. 2006b. "The MetLife Study of Alzheimer's Disease: The Caregiving Experience." Research Report. MetLife Mature Market Institute.

Meuser, T.M., and S.J. Marwit. 2001. "A comprehensive, stage-sensitive model of grief in dementia caregiving." Gerontologist 41 (5): 658-670.

National Alliance for Caregiving (NAC). 2009. Caregiving in the U.S. Research Report, in collaboration with AARP.

National Association for Home Care and Hospice (NAHH). 2008. "The Basic Statistics about Home Care: Updated 2008." Washington, DC. http://www.nahc.org/facts/08HC STATS.pdf

OECD. 2011. Family Database: Formal care and education for very young children. Directorate for Employment, Labour, and Social Affairs. Organization for Economic Co-operation and Development.

Peisner-Feinberg, Ellen S., Margaret R. Burchinal, Richard M. Clifford, Noreen Yazejian, Mary L. Culkin, Janice Zelazo, Carollee Howes, Patricia Byler, Sharon L. Kagan, and Jean Rustici. 1999. "The Children of the Cost, Quality, and Outcomes Study Go to School." Public Report. Chapel Hill, NC: Frank Porter Graham Child Development Center.

Peters, Louise and Ken Sellick. 2006. "Quality of life of cancer patients receiving inpatients and home-based palliative care.” Journal of Advanced Nursing 53 (5): 524-533.

PHI. 2009. "Who are direct-care workers?” Facts Report No. 3. Bronx, New York. Paraprofessional Healthcare Institute.

Pinquart, Martin and Silvia Sörensen. 2003. "Differences between caregivers and noncaregivers in psychological health and physical health: a meta-analysis." Psychology and aging 18 (2): $250-67$. 
Powell, Lisa M. 1997. "The Impact of Child Care Costs on the Labor Supply of Married Mothers: Evidence from Canada." The Canadian Journal of Economics 30 (3): 577-594.

Robinson, Andrew, Emma Lea, Lynn Hemmings, Gillian Vosper, Damhnat Mccann, Felicity Weeding, and Roger Rumble. 2011. "Seeking respite : issues around the use of day respite care for the carers of people with dementia." Ageing \& Society : 1-23.

Schacke, Claudia and Susanne R. Zank. 2006. "Measuring the Effectiveness of Adult Day Care as a Facility to Support Family Caregivers of Dementia Patients." Journal of Applied Gerontology 25 (1): 65-81.

Schweinhart, L.J., H.V. Barnes, and D.P. Weikart. 1993. Significant benefits: The HighScope Perry Preschool study through age 27 (Monographs of the High/Scope Educational Research Foundation, 10). Ypsilanti: High/Scope Press.

Sörensen, S., M. Pinquart, and P. Duberstein. 2002. "How Effective are Interventions with Caregivers? An Updated Meta-Analysis.” The Gerontologist 42 (3): 356-372.

Sörensen, S., P. Duberstein, D. Gill, and M. Pinquart. 2006. "Dementia care: mental health effects, intervention strategies, and clinical implications." Lancet neurology 5 (11): 961973.

Stuckey Jon C., Marcia M. Neundorfer, and Kathleen A. Smyth. 1996. "Burden and Well-being: The Same Coin or Related Currency?” The Gerontologist 36 (5): 686-693.

Warner, M.E. 2009. Child Care Multipliers: Stimulus for the States. Manuscript. Cornell University.

Zank, Susanne R., and Claudia Schacke. "Evaluation of geriatric day care units: Effects on patients and caregivers." Journals of Gerontology: Series B: Psychological Sciences 57 (4): $348-357$. 